\title{
Vulvar Squamous Cell Carcinoma with Tumor Giant Cells
}

National Cancer Institute

\section{Source}

National Cancer Institute. Vulvar Squamous Cell Carcinoma with Tumor Giant Cells. NCI

Thesaurus. Code C40289.

An aggressive squamous cell carcinoma that arises from the vulva and is characterized by the prominence of malignant giant cells. 